\title{
Virulence in Puccinia recondita f. sp. tritici Isolates from Canada to Genes for Adult-Plant Resistance to Wheat Leaf Rust
}

\author{
J. A. Kolmer, Research Scientist, Agriculture and Agri-Food Canada, Cereal Research Centre, 195 Dafoe Road, \\ Winnipeg, Manitoba, Canada, R3T 2M9
}

\begin{abstract}
Kolmer, J. A. 1997. Virulence in Puccinia recondita f. sp. tritici isolates from Canada to genes for adult-plant resistance to wheat leaf rust. Plant Dis. 81:267-271.

Sixty-seven isolates of Puccinia recondita f. sp. tritici collected in Canada were tested for virulence to adult plants of Thatcher near-isogenic wheat lines with leaf rust resistance genes $L r 13$, $L r 22 a, L r 34, L r 35$, and $L r 13$ and Lr34 combined. All of the isolates had low infection type to the Thatcher lines with $L r 22 a$ and $L r 35$. All isolates had lower infection type and lower rust severity on the Thatcher line with $\operatorname{Lr} 34$ compared with Thatcher. The isolates were polymorphic for virulence to the Thatcher line with $\operatorname{Lr} 13$; many isolates were completely virulent to this line, and other isolates produced very low or intermediate avirulent infection type. On the Thatcher line with $\operatorname{Lr} 13$ and $L r 34$ combined, many isolates had infection type and rust severity similar to the Thatcher line with $L r 34$, while other isolates had lower infection type and rust severity compared with the single-gene lines with $\operatorname{Lr} 13$ or Lr34. Fifteen isolates with low, intermediate, and high infection type to adult plants with $\operatorname{Lrl3}$ were tested for infection type on seedling plants of the Thatcher lines with resistance genes Lr13, Lr22a, Lr34, Lr35, and Lr37, and on Thatcher lines with $L r 13$ paired with seedling resistance genes. Most isolates were completely virulent to seedling plants with $L r 13$ and $L r 22 a$. Plants with $L r 37$ expressed seedling resistance to all isolates tested. Seedling plants with $L r 34$ had lower infection types to all isolates compared with Thatcher. Seedlings with $\mathrm{Lr} 35$ had high infection types to most isolates, with varying amounts of chlorosis. The Thatcher lines with $L r 13$ plus seedling resistance genes were most resistant to the isolates that had very low infection types on adult plants with $\operatorname{Lr} 13$ and intermediate infection types on plants with seedling resistance genes. Genes $L r 22 a, L r 35$, and $L r 37$ offer additional sources of highly effective leaf rust resistance in wheat.
\end{abstract}

Additional keywords: specific virulence, Triticum aestivum

Virulence surveys of cereal rust fungi have traditionally used differential host lines that express resistance in the primary leaves of seedling plants. Wheat leaf rust (Puccinia recondita Roberge ex Desmaz. f. sp. tritici Eriks. \& E. Henn.) virulence phenotypes can be characterized on host seedling differential sets within 35 days from receipt of the rust collection. In the annual survey of physiologic specialization in $P$. recondita f. sp. tritici in Canada, more than 250 single-uredinial isolates are tested for virulence on differential sets within a 2month period $(12,15)$. Inoculation of spores from single uredinia onto differential sets of seedling plants minimizes the amount of rust required and also the amount of time and space required to grow the differential sets. Surveys of wheat leaf

Corresponding author: J. A. Kolmer

E-mail: jkolmer@em.agr.ca

Contribution No. 1675, Agriculture and Agri-Food Canada.

Accepted for publication 8 December 1996.

Publication no. D-1997-0115-04R

(C) 1997 Department of Agriculture and Agri-

Food, Government of Canada rust in Canada using seedling differentials have been very useful in describing virulence variation, geographic distribution of virulence phenotypes, and how leaf rust phenotypes change in response to host selection $(11,14,15)$

The most durable leaf rust resistance in wheat (Triticum aestivum) is conditioned by adult-plant resistance genes $(1,23)$. Genes Lrl3 and Lr34 are important in North American spring wheats, in breeding programs in South America (16), and in the CIMMYT program (24). However, the frequency of $P$. recondita $\mathrm{f}$. sp. tritici isolates with virulence to either of these genes has not been directly measured in leaf rust virulence surveys conducted in North America $(12,15,20)$. Large-scale testing of $P$. recondita f. sp. tritici isolates for virulence to adult-plant genes requires more greenhouse space, more inoculum of the individual survey isolates compared with testing on seedling differentials, and 2 to 3 months for the plant to reach the flag leaf stage, when resistance is most effective. Genes $L r 22 a$ and Lr35 are adult-plant resistance genes that were derived from species related to wheat $(5,10)$. These genes have not yet been widely deployed in wheat cultivars and are sources of highly effective leaf rust resistance.
Gene Lrl3 was shown previously to interact with other leaf rust resistance genes in cultivars and near-isogenic lines to condition a higher level of resistance than expressed by lines with the single genes (13,25). Lrl3 enhances the effect of certain seedling resistance genes that by themselves confer an intermediate infection type (13). Since these tests were conducted with seedling plants, the effect of the Lrl3 adult-plant infection type for each isolate on the degree of interaction for resistance was not determined. The objective of this study was to characterize a representative collection of $P$. recondita $\mathrm{f}$. sp. tritici isolates from Canada for virulence to adult plants of near-isogenic lines with resistance genes Lr13, Lr22a, Lr34, Lr35, and Lr13 and Lr34 combined. Information on specific virulence to adult-plant resistance genes in a large representative collection of $P$. recondita f. sp. tritici isolates will provide an estimate of the frequency of isolates in the general population with virulence to these genes and hence their potential effectiveness in breeding programs. Selected isolates were further tested to determine the effect of isolates with different infection type to adult plants with Lrl3 on interaction for enhanced resistance between $\mathrm{Lrl3}$ and seedling resistance genes. Seedling plants with $L r 22 a, L r 34$, Lr35, and Lr37 were also tested with selected isolates to determine if these genes expressed any discernible resistance under normal ambient greenhouse conditions.

\section{MATERIALS AND METHODS}

$P$. recondita f. sp. tritici isolates. Fiftysix isolates from the 1994 survey (17) were used in this study. The isolates from 1994 were chosen based on their three-letter virulence phenotype designation to the 12 seedling differentials in the Prt nomenclature (19). Isolates from 27 different virulence phenotypes collected in 1994 were tested. Multiple isolates of the most common virulence phenotypes were included to determine if variation for virulence to the adult-plant resistance genes occurred within them. Phenotypes MBR (nine isolates tested), MFM (eight isolates tested), and TDG (four isolates tested) were the three most common in Manitoba and Saskatchewan in 1994. Three isolates of PBL, the most common phenotype in Ontario and Quebec in 1994, were included. Seven isolates from the 1989 survey in Canada (12) were included, as were four isolates 
Table 1. Year of collection, wheat host of origina, isolate number, virulence phenotype ${ }^{\mathrm{b}}$, and infection type ${ }^{c}$ for adult plants of Thatcher near-isogenic wheat lines with Lr13 and Lr13,34 of single uredinial isolates of Puccinia recondita f. sp. tritici collected in Canada

\begin{tabular}{|c|c|c|c|c|c|c|}
\hline \multirow[b]{2}{*}{ Year } & \multirow[b]{2}{*}{ Host } & \multirow{2}{*}{$\begin{array}{c}\text { Isolate } \\
\text { number }\end{array}$} & \multirow{2}{*}{$\begin{array}{l}\text { Virulence } \\
\text { phenotype }\end{array}$} & \multicolumn{2}{|c|}{ TcLr13 } & \multirow[b]{2}{*}{ TcLr13,34 } \\
\hline & & & & March & June & \\
\hline 1954 & Spring wheat & $56-1$ & $\mathrm{BBB}$ & ; & $; 1+$ & $0 ; / \mathrm{TR}^{\mathrm{d}}$ \\
\hline 1959 & Spring wheat & $59-1$ & MBB & ; & ; & $0 ; / \mathrm{TR}$ \\
\hline 1959 & Spring wheat & $59-2$ & SBD & ; & ; & $0 ; / \mathrm{TR}$ \\
\hline 1964 & Spring wheat & $64-1$ & $\mathrm{CHB}$ & ; & ; & $0 ; / \mathrm{TR}$ \\
\hline 1989 & Spring wheat & $89-1$ & KBG & $2+$ & $; 12-$ & $0 ; / \mathrm{TR}$ \\
\hline 1989 & Spring wheat & $89-2$ & MBB & ; & ; & $0 ; / \mathrm{TR}$ \\
\hline 1989 & Spring wheat & $89-3$ & MBG & ; & $12-$ & $23 / 5$ \\
\hline 1989 & Spring wheat & $89-4$ & MDB & ;12 & 4 & $0 ; / \mathrm{TR}$ \\
\hline 1989 & Spring wheat & $89-5$ & TBB & $2+n$ & 12 & $0 ; / \mathrm{TR}$ \\
\hline 1989 & Spring wheat & $89-6$ & TBG & $; 1$ & 12 & $0 ; 1-/ \mathrm{TR}$ \\
\hline 1989 & Spring wheat & $89-7$ & TDG & $; 11+$ & 12 & $0 ; 1 / \mathrm{TR}$ \\
\hline 1994 & QW572 & $178-1$ & $\mathrm{CBB}$ & 4 & $22+$ & $22+/ 5$ \\
\hline 1994 & CDC Teal $(\operatorname{Lr} 1,13,34)$ & $87-1$ & KBG & 4 & 4 & $23 / 5-10$ \\
\hline 1994 & Little Club & $139-1$ & KBG & 4 & 4 & $23 / 10$ \\
\hline 1994 & Winter wheat & $63-3$ & KDG & 4 & 4 & $0 ; / \mathrm{TR}$ \\
\hline 1994 & Belvedere & $147-1$ & LBB & $; 1$ & $12+$ & $12 / 10$ \\
\hline 1994 & Columbus $(\operatorname{Lr} 13,16)$ & $115-1$ & MBB & 4 & 4 & $23 / 20$ \\
\hline 1994 & Red Bobs & $156-1$ & MBG & 4 & 4 & $23+/ 30$ \\
\hline 1994 & Spring wheat & $183-1$ & MBG & 4 & 4 & $23+/ 40$ \\
\hline 1994 & Columbus $(\operatorname{Lr} 13,16)$ & $57-1$ & MBQ & 2 & $33+$ & $; 12-/ 3$ \\
\hline 1994 & Spring wheat & $98-2$ & MBR & 4 & 4 & ;12/ TR \\
\hline 1994 & Winter wheat & $68-1$ & MBR & $2++$ & 12 & $23 / 5$ \\
\hline 1994 & Columbus $(\operatorname{Lr} 13,16)$ & $128-1$ & MBR & 4 & 4 & $23 / 10-20$ \\
\hline 1994 & Genesis (Lr13) & $17-1$ & MBR & 4 & 4 & $12 / \mathrm{TR}$ \\
\hline 1994 & Spring wheat & $76-1$ & MBR & 4 & 4 & ;12/ TR \\
\hline 1994 & Katepwa (Lr13) & $4-1$ & MBR & 4 & 4 & ;1/ TR \\
\hline 1994 & AC Domain $(\operatorname{Lr} 10,12,16,34)$ & $41-1$ & MBR & $2++$ & 4 & ;1- / TR \\
\hline 1994 & Kenya Farmer & $45-1$ & MBR & $2++$ & 12 & ; / TR \\
\hline 1994 & Little Club & $48-1$ & MBR & 4 & 4 & ;/ TR \\
\hline 1994 & Spring wheat & $101-1$ & MCB & 4 & 4 & $0 ; / \mathrm{TR}$ \\
\hline 1994 & Neepawa (Lr13) & $19-1$ & MCR & 4 & 4 & $33+/ 20$ \\
\hline 1994 & BW 186 & $56-1$ & MCR & 4 & 4 & $3 / 30$ \\
\hline 1994 & Spring wheat & $106-1$ & MDB & $22-$ & 23 & $; 12-/ 5$ \\
\hline 1994 & Little Club & $34-1$ & MDG & $; 1$ & $12-$ & ;1/ TR \\
\hline 1994 & CDC Teal $(\operatorname{Lr} 1,13,34)$ & $87-2$ & MDM & 4 & 4 & $23+/ 10$ \\
\hline 1994 & Spring wheat & $75-1$ & MDM & 4 & 4 & $33+/ 30$ \\
\hline 1994 & Winter wheat & $84-1$ & MDR & 2 & 12 & ;1/ 3 \\
\hline 1994 & Glenlea $(\operatorname{Lr} 1,34)$ & $43-1$ & MDR & 2 & $; 12-$ & ;12-/ TR \\
\hline 1994 & Glenlea $(\operatorname{Lrl} 1,34)$ & $31-2$ & MDR & $2-$ & ;12- & ;1-/ TR \\
\hline 1994 & Spring wheat & $89-5$ & MFB & $2++$ & 4 & $0 ; / \mathrm{TR}$ \\
\hline 1994 & Spring wheat & $94-1$ & MFM & 4 & 4 & $23+/ 40$ \\
\hline 1994 & Spring wheat & $73-1$ & MFM & $2++$ & $22+$ & ;1/ TR \\
\hline 1994 & Spring wheat & $71-1$ & MFM & $2++$ & $22+$ & $22+/ 10$ \\
\hline 1994 & Roblin $(\operatorname{Lr} 1,10,13,34)$ & $143-2$ & MFM & $2++$ & $22+$ & $23 / 10$ \\
\hline 1994 & Glenlea $(\operatorname{Lr} 1,34)$ & $3-1$ & MFM & $2++$ & 4 & ;1/ TR \\
\hline 1994 & Spring wheat & $67-1$ & MFM & $2++$ & $22+$ & ;2/3 \\
\hline 1994 & Roblin $(\operatorname{Lrl} 1,10,13,34)$ & $12-1$ & MFM & $2++$ & $2+3$ & $; 12-/ 3$ \\
\hline 1994 & Roblin $(\operatorname{Lrl} 1,10,13,34)$ & $51-1$ & MFM & $2++$ & 4 & ;1/ TR \\
\hline 1994 & Glenlea $(\operatorname{Lr} 1,34)$ & $118-1$ & NBB & $; 1$ & ; & $0 ; / \mathrm{TR}$ \\
\hline 1994 & Klein Titan (Lr3ka) & $152-1$ & PBL & 4 & 4 & $23+/ 20$ \\
\hline 1994 & $\operatorname{Max}$ & $224-1$ & PBL & 4 & 4 & $23+/ 20$ \\
\hline 1994 & Winter wheat & $212-1$ & PBL & 4 & 4 & $23+/ 50$ \\
\hline 1994 & QW572 & $178-2$ & PBR & 2 & 12 & $23+/ 20$ \\
\hline 1994 & Thatcher- $\operatorname{Lr} 9$ & $13-2$ & PDD & $2++$ & 4 & $23 / 5$ \\
\hline 1994 & AC Domain $(\operatorname{Lr} 10,12,16,34)$ & $41-3$ & TBB & 4 & 4 & $23 / 10$ \\
\hline 1994 & Biggar (Lr13) & $114-1$ & TBG & 4 & 4 & $23+/ 5$ \\
\hline 1994 & Stoa & $144-1$ & TDB & 2 & 2 & $23 / 5-20$ \\
\hline 1994 & Winter wheat & $70-1$ & TDB & $2 \mathrm{n}$ & 4 & $0 ; / \mathrm{TR}$ \\
\hline 1994 & Winter wheat & $105-1$ & TDB & 2 & $; 12$ & ;/ TR \\
\hline 1994 & Marshall & $10-1$ & TDG & 4 & $22+$ & $23 / 5$ \\
\hline 1994 & Little Club & $36-1$ & TDG & 4 & $2+3$ & $; 12 / 5$ \\
\hline 1994 & Winter wheat & $69-1$ & TDG & $22+$ & 12 & $0 ; / \mathrm{TR}$ \\
\hline 1994 & Spring wheat & $78-1$ & TDG & 4 & 4 & $34 / 20-30$ \\
\hline 1994 & Little Club & $37-1$ & TFB & 4 & 4 & $23 / 5$ \\
\hline 1994 & Spring wheat & $80-1$ & TFB & ;12 & $12-$ & ;1/ TR \\
\hline 1994 & Marshall & $10-3$ & TFG & 4 & 4 & $23 / 20$ \\
\hline 1994 & Kenya Farmer & $32-1$ & TFM & $22+$ & 12 & $0 ; / \mathrm{TR}$ \\
\hline
\end{tabular}

${ }^{\mathrm{a}}$ Where known, wheat cultivar and leaf rust resistance genes are listed. Spring wheat indicates collections obtained from farm fields where identity of cultivar was not known. Cultivars Little Club and Kenya Farmer are susceptible to leaf rust, as were winter wheats. All other have some effective leaf rust resistance.

${ }^{b}$ Virulence phenotypes are given in the three-letter code used in the Prt nomenclature (19).

${ }^{c}$ Infection types as described in the Prt nomenclature (19). Most common infection types listed first.

${ }^{\mathrm{d}}$ Leaf rust severity (\%) estimated using the Cobb scale (21). TR $=$ trace level of uredinia. that were collected before 1966 . When known, the wheat line or cultivar from which the leaf rust isolates were collected was recorded, and the leaf rust resistance genotype was noted (Table 1). Collections from farm fields were recorded as spring wheat.

Each isolate was increased on primary leaves of Little Club wheat seedlings, in $10-\mathrm{cm}$-diameter pots, that had been treated at emergence with maleic hydrazide to prevent further leaf formation. Plants were inoculated after the first leaves had fully formed by atomizing a suspension of Dustrol (Ciba-Giegy Canada, Mississauga, ON ) nonphytotoxic industrial oil (300 to 500 $\mu \mathrm{l})$ mixed with $1 \mathrm{mg}$ of urediniospores. The seedling plants were placed in a dew chamber at $15^{\circ} \mathrm{C}$ for at least $18 \mathrm{~h}$, then removed to a greenhouse bench at 15 to $25^{\circ} \mathrm{C}$ with $8 \mathrm{~h}$ of supplemental fluorescent lighting. Clear plastic cylinders without tops were placed around each pot to reduce cross-contamination between isolates. After 10 to 14 days, urediniospores from each isolate were collected into size 00 gelatin capsules using a cyclone spore collector (24). The urediniospores were dried in a desiccator overnight, and then placed in glass tubes and stored at $-80^{\circ} \mathrm{C}$. Isolates were heat-shocked for $5 \mathrm{~min}$ at $40^{\circ} \mathrm{C}$ prior to inoculation on adult plants.

Host materials. Flag leaves of Thatcher near-isogenic lines RL 4031 (TcLr13), RL 6044 (TcLr22a), RL 6058 (TcLr34), RL 6082 (TcLr35), and RL 6114 (TcLr13,34) and Thatcher were inoculated at heading with all selected $P$. recondita $\mathrm{f}$. sp. tritici isolates. Thatcher has the adult-plant resistance gene $L r 22 b$. Almost all P. recondita f. sp. tritici isolates found in North America are virulent to this gene. Adult plants were inoculated in two separate tests. Lines TcLr13, TcLr22a, TcLr34, and Thatcher were inoculated with all leaf rust isolates in March 1995. All isolates were also tested on adult plants of TcLr13, TcLr35, TcLr13,34, and Thatcher in June 1995. The isolates were tested twice on TcLrl3 because they were polymorphic for virulence to this line. In both tests, four plants (one plant of each line) were grown together in 15-cm-diameter fiber pots in a sand-peat-soil mixture. The plants were grown in a greenhouse at 15 to $25^{\circ} \mathrm{C}$, with $8 \mathrm{~h}$ of supplemental fluorescent lighting, and were fertilized with 20-20-20 NPK as needed. The plants were trimmed to two tillers each. Heads were removed from the plants after emergence to delay senescence of the flag leaves. Flag leaves in each pot were inoculated by atomizing 2 to $3 \mathrm{mg}$ of urediniospores from a single $P$. recondita $\mathrm{f}$. sp. tritici isolate in $500 \mu \mathrm{l}$ of oil. After inoculation, the plants were placed in a dew chamber at $15^{\circ} \mathrm{C}$ for at least $18 \mathrm{~h}$. After incubation, the plants were placed in greenhouses between 15 and $20^{\circ} \mathrm{C}$, and the infection types (IT) on the flag leaves were evaluated 14 days later. Infection types 
were read according to the Stakman scale (26) and the scale used by Long and Kolmer (19): $0=$ no visible sign of infection, ; $=$ small hypersensitive flecks, $1=$ small uredinia surrounded by necrosis, $2=$ small uredinia surrounded by chlorosis, $3=$ moderate uredinia without chlorosis, $4=$ large uredinia without chlorosis, $+=$ slightly larger uredinia than expected for the IT, $=$ slightly smaller uredinia than expected for the IT, $\mathrm{c}=$ more chlorosis than expected for the IT, and $\mathrm{X}=$ mesothetic mixture of uredinia and flecks. Isolates that produced infection type 0 to $2++$ were considered avirulent, and those with IT 3 to 4 were considered virulent. The most common IT was listed first, followed by less frequent IT. The percentage of leaf rust severity on TcLr34, TcLr13,34, and Thatcher for each isolate was estimated using the modified Cobb scale (21). Infection type on each resistant Thatcher line was compared to the susceptible check Thatcher for each isolate.

Fifteen of the $P$. recondita $\mathrm{f}$. sp. tritici isolates that had very low, intermediate, and high IT to adult plants of TcLrl3 were inoculated to seedlings of lines TcLr13, RL 6000 (TcLr2a), RL 6123 (TcLr2a,13), RL 6048 (TcLr11), RL 6127 (TcLr11,13), RL6008 (TcLr17), RL 6129 (TcLr13,17), RL 6049 (TcLr30), RL 6134 (TcLr13,30), RL 6007 (TcLr3ka), RL 6126 (TcLr3ka,13), TcLr22a, TcLr34, TcLr13,34, TcLr35, RL 6081 (TcLr37), and Thatcher. Eight to 12 seeds of each line were planted in clumps in fiber flats filled with sand-peat-soil. Seedlings were grown in a greenhouse at 15 to $25^{\circ} \mathrm{C}$ with $8 \mathrm{~h}$ of supplemental fluorescent light. Plants were inoculated with 2 to $3 \mathrm{mg}$ of urediniospores suspended in $500 \mu \mathrm{l}$ of oil 8 days after planting, when the first leaves were fully expanded. Plants were incubated in a dew chamber at $15^{\circ} \mathrm{C}$ for at least $18 \mathrm{~h}$, then removed to a greenhouse bench at 15 to $20^{\circ} \mathrm{C}$. Infection types were evaluated 12 days after inoculation $(19,26)$.

\section{RESULTS}

Adult-plant test. All isolates tested were avirulent on adult plants of TcLr22a and TcLr35, and had lower IT and rust severity on TcLr34 compared with Thatcher. All isolates had IT 2- on plants of TcLr22a, and IT ; on plants of TcLr35. On adult plants of TcLr34, all isolates had IT 23 , with an estimated rust severity of 20 to $50 \%$. On Thatcher, all isolates had IT 4 , with severity of $90 \%$, except isolate 59-2 (SBD), which was avirulent to gene $L r 22 b$ in Thatcher and had IT ; on Thatcher and all the Thatcher lines. The resistance response of TcLr34 could consistently be recognized by a direct comparison of the susceptible check Thatcher inoculated with the same isolates.

The tested isolates were polymorphic for virulence to adult plants with Lrl3 (Table 1). In the March test, 13 isolates had IT ; to
$; 1,25$ isolates had IT $2-$ to $2++$, and 29 isolates had IT 4 . In the June test, 10 isolates had IT ; to ; 12, 23 isolates had IT 12 to $2+3$, and 34 isolates had IT 4 . Most isolates produced the same or similar IT on TcLrl3 between the two different tests. Of 67 isolates tested, only 11 had different avirulence-virulence ratings between the two tests. Three isolates had IT 4 in the March test and had IT 22+ to $2+3$ in the June test. Eight isolates had IT ;12 to 2++ in March and IT 4 in June. Isolates with IT ; to ; 1 had low IT in both tests.

Isolates 56-1 (BBB), 64-1 (CHB), and 59-1 (MBB) were collected before the release of wheat cultivars with $\mathrm{Lrl3}$ in western Canada. These isolates had IT ; on adult plants of TcLrl3 (Table 1). Six of the isolates collected in 1989 had low IT on adult plants of TcLrl3 in both tests, and one isolate had IT ;12 in March and IT 4 in the June test. None of the isolates from 1989 were virulent to TcLrl3 in both tests. Twenty-one of the isolates collected in 1994 had low IT on TcLrl3 in both tests, and 25 had high IT. Variation for virulence on TcLrl3 occurred within virulence phenotypes as defined by IT on seedling differentials. Of the nine MBR isolates tested, two had low IT to Lrl3 in both tests, one had a low IT in March and a high IT in June, and seven had high IT in both tests. Of the eight MFM isolates tested, five had low IT to TcLrl3 in both tests, two had low IT in March and high IT in June, and one had high IT in both tests. Of the four TDG isolates tested, one had low IT on TcLrl3 in both tests, two had high IT in March and low IT in June, and one had high IT on TcLrl3 in both tests. A $2 \times 2$ contingency test (27) (hosts: lines with $L r 13$ versus those without; $P$. recondita $\mathrm{f}$. sp. tritici: isolates virulent to $L r 13$ versus those avirulent) showed that isolates collected in 1994 with high IT to TcLr13 in March and June were significantly associated with hosts with $\operatorname{Lr} 13\left(X^{2}=5.08,1 \mathrm{df}\right)$. However, six isolates that had IT 2 to $2+$ to TcLrl3 in both tests were collected from cultivars or lines with $\operatorname{Lr} 13$.

Nineteen isolates collected in 1994, which had IT 23 on adult plants of TcLr34 and IT 4 on plants with TcLrl3, had IT 23 and varied for rust severity on adult plants of TcLr13,34 (Table 1). Sixteen isolates had low IT on plants of TcLrl3 in both tests and had very low IT and low rust severity on adult plants of TcLr13,34. However, seven isolates from 1994 had IT 4 on plants of TcLrl3, yet had IT 0 ; to 12 and low rust severity on adult plants of TcLr13,34 (Table 1). Four other isolates had low IT on TcLrl3 in both tests and IT 23 on plants of $\mathrm{Tc} L r 13,34$. Eight isolates that varied for virulence to TcLrl3 in the two tests had low IT on plants with TcLr13,34, and two other isolates that had different readings on TcLrl3 had IT 23 to plants of TcLr13,34.
Seedling test. Most isolates tested had IT $3+$ on plants with TcLrl3 in the seedling test (Table 2). Two isolates, which were avirulent to TcLrl3 in the adult-plant test, produced moderate-large uredinia surrounded by chlorosis (IT $3 \mathrm{c}$ to $3+\mathrm{c}$ ) on seedling plants of TcLrl3. Enhancement of seedling resistance genes by $\mathrm{Lrl3}$ was most strongly and frequently expressed to isolates 118-1 (NBB), 89-2 (MBB), and 56-1 (BBB), which had IT ; on adult plants of TcLr13. These isolates also had intermediate IT on lines with genes $L r 11, \operatorname{Lr} 17$, $L r 30$, and $L r 3 k a$. Thatcher lines with gene pairs Lr11, Lr13; Lr17, Lr13; Lr30, Lr13; and Lr3ka, Lrl3 expressed enhanced resistance relative to the single gene lines to these three isolates. Thatcher lines with gene pairs $L r 11,13$; Lr30, 13; and Lr3ka, 13 also had enhanced resistance relative to the single gene lines to isolate $80-1$ (TFB), which had IT 12 on adult plants of TcLrl3. Enhancement of seedling resistance by Lrl3 was observed less frequently to the isolates that had intermediate or high IT on adult plants of TcLrl3 (Table 2). For these isolates in most cases, IT on the lines with the paired resistance genes were the same as on the single gene lines.

All isolates tested had high IT on seedling plants of Tc $L r 22 a$, IT 23 on seedling plants of TcLr34, and IT X on seedling plants of TcLr37 (Table 2). Most isolates had IT 33+ with varying amounts of chlorosis to seedling plants of TcLr35. Isolate 178-2 (PBR) had IT ;22+ on plants with TcLr35. Interaction for enhanced resistance was not observed in seedling plants of TcLr13,34, as compared with TcLr34.

\section{DISCUSSION}

All of the tested isolates were avirulent to the adult-plant resistance genes $L r 22 a$ and $L r 35$, and produced intermediate IT to adult plants with Lr34. The Thatcher lines with $L r 22 a$ and $L r 35$ are highly resistant in rust nursery tests (J. A. Kolmer, unpublished). The lack of isolates with virulence to these genes and the high levels of field resistance that they confer indicate that genes $L r 22 a$ and $L r 35$ would provide effective resistance in a breeding program. The isolates were highly polymorphic for virulence to Lr13. With the exception of isolate 59-2 (SBD), all isolates were virulent to $L r 22 b$ in Thatcher.

Gene $L r 22 a$ was derived from Triticum taushii (5) and currently is present only in the Canadian cultivar AC Minto (J. A. Kolmer, unpublished). Since this cultivar has been grown in a limited amount, the $P$. recondita $\mathrm{f}$. sp. tritici population in Canada has not been widely exposed to $L r 22 a$. AC Minto (Lr11, Lr13, Lr22a) and TcLr22a are highly resistant in the field to leaf rust (J. A. Kolmer, unpublished). Resistance conditioned by $L r 22 a$ was not evident in the seedling test. Virulence to Lr22a should be evaluated in juvenile or adult plants. 
Gene Lr34 has been widely used in North American spring wheats over the last 30 years (16). All isolates had intermediate IT 23 and lower rust severity to TcLr34 compared with the susceptible check Thatcher. It is remarkable that isolates with equal virulence to TcLr34 and Thatcher have not yet been found. Gene Lr34 was initially described as a modifier of $\mathrm{Lrl3}$ in the cultivar Frontana (8) and only later isolated, characterized singly, and mapped to chromosome 7D (2). In the field, lines with only Lr34 can have variable amounts of leaf rust severity, with a mixture of small and large uredinia. At times, lines with only Lr34 can appear to be susceptible. Cultivars and lines with Lr34 combined with other genes that condition effective resistance have been highly resistant in the field $(3,4,9)$. Resistance conditioned by $L r 34$ could be distinguished in the seedling test, although in other tests seedlings with Lr34 were indistinguishable from the susceptible check Thatcher $(3,4,9)$. Dyck and Samborski (7) originally isolated $\mathrm{Lr} 34$ in seedling plants that were tested in cooler temperatures and reduced light intensities.

Gene Lr35 was derived from Aegilops speltoides (10) and is not present in any commercially grown wheat cultivar. Although resistance conditioned by TcLr35 is optimally evaluated on flag leaves, primary leaves of seedling plants had variable amounts of chlorosis surrounding the uredinia. Kerber and Dyck (10) showed that resistance was expressed starting at the second leaf stage. In a Marquis cultivar background, male gametes with Lr35 had a lower transmission rate, which resulted in distorted segregation ratios. Transmission of male gametes with $L r 35$ was improved in a Thatcher background (10). Gene Lr35 is linked with $\mathrm{Sr} 39$ and is associated with higher protein content in a Marquis back- ground (E. R. Kerber, personal communication).

Gene Lrl3 was first used in Canada in the cultivar Manitou, which was released in 1966. Manitou was highly resistant when first released. By 1974, however, leaf rust ratings on Manitou had increased to $60 \%$ (18). The widespread use of cultivars with $L r 13$ selected $P$. recondita f. sp. tritici phenotypes with virulence to this gene. Since Manitou, every cultivar released by the Cereal Research Centre in Winnipeg, with the exception of AC Domain, has had Lr13. Cultivars with only Lr13, however, still have some effective resistance. Leaf rust severities on Neepawa and Katepwa in rust nursery tests in recent years have generally been 30 to $50 \%$, with moderately resistant to moderately susceptible responses (J. A. Kolmer, unpublished). Despite the widespread use of cultivars with Lr13, isolates avirulent to this gene have been maintained in the $P$. recondita $\mathrm{f}$. $\mathrm{sp}$. tritici population in Manitoba and Saskatchewan. Isolates avirulent to Lr13 may originate from susceptible winter wheats in the southern U.S. plains. There was an association between isolates with virulence to $\operatorname{Lr} 13$ and host cultivars known to have Lr13. However, isolates that had intermediate IT 2 to $2+$ to TcLrl3 were also collected from hosts with this gene. Isolates with intermediate IT to $\operatorname{Lr} 13$ are still capable of infection and reproduction on cultivars with this gene. This may help explain why isolates avirulent to $\operatorname{Lrl3}$ can still be found.

In this study, the frequency of virulence to $\mathrm{Lr} 13$ was highest in isolates collected in 1994. As isolates virulent to $L r 13$ increase in frequency, the effectiveness of Lrl3 resistance will be eroded. If virulence to Lr13 continues to increase, cultivars with combinations of $\mathrm{Lrl3}$ and other genes (e.g., Roblin Lr1, Lr10, Lr13, Lr34; Co- lumbus Lr13, Lr16; AC Minto Lr11, Lr13, $L r 22 a$; AC Cora $L r 13, L r 21)$ may start to have higher leaf rust severities and response readings in rust nurseries and farm fields.

All of the isolates that varied for avirulence-virulence to $\mathrm{Lr} 13$ in the two tests had intermediate IT in one of the tests. Isolates with intermediate IT are probably heterozygous for virulence to $\operatorname{Lrl3}$ and may be more sensitive to temperature and light conditions than are homozygous avirulent isolates. Virulence to $\operatorname{Lrl3}$ was determined to be conditioned by a single gene in $P$. recondita f. sp. tritici $(\mathrm{P}$. L. Dyck, personal communication).

Most isolates that produced high IT on adult plants of TcLrl3 in both tests and IT 23 on adult plants of TcLr34 produced IT 23 with variable rust severity on plants of TcLr13,34. However, some isolates that were completely virulent to TcLr13 in both tests produced very low IT on plants of TcLr13,34. The isolates were tested on the TcLr34 and TcLr13,34 lines at different times, which could have affected the results since expression of $L r 34$ can be influenced by temperature (22). Selected $P$. recondita f. sp. tritici isolates from the 1995 virulence survey in Canada were tested on adult plants of TcLr13, TcLr34, and TcLr13,34 simultaneously (J. A. Kolmer, unpublished). A number of isolates from the 1995 survey also produced IT 3+ on TcLr13, IT 23 on TcLr34, and IT 0; on TcLr13,34. The IT expressed by adult plants with $L r 34$ generally has been stable in the ambient greenhouse conditions in Winnipeg in recent virulence surveys and in previous work (9).

Genes Lrl3 and Lr34 apparently can interact for enhanced resistance even to $P$. recondita $\mathrm{f}$. $\mathrm{sp}$. tritici isolates that produce a moderate to high IT on plants with both genes singly. Previously, German and

Table 2. Infection types ${ }^{\mathrm{a}}$ of Puccinia recondita f. sp. tritici isolates with low, intermediate, and high infection types to adult plants of Thatcher nearisogenic lines with $\operatorname{Lrl3}$ to seedlings of near-isogenic Thatcher lines with single and two genes for leaf rust resistance

\begin{tabular}{|c|c|c|c|c|c|c|c|c|c|c|c|c|c|c|c|}
\hline \multirow[b]{2}{*}{ Thatcher line } & \multicolumn{15}{|c|}{ Isolates } \\
\hline & $\begin{array}{c}\text { NBB } \\
118-1\end{array}$ & $\begin{array}{c}\text { MBB } \\
89-2\end{array}$ & $\begin{array}{c}\text { BBB } \\
56-1\end{array}$ & $\begin{array}{l}\text { TFB } \\
80-1\end{array}$ & $\begin{array}{c}\text { PBR } \\
178-2\end{array}$ & $\begin{array}{c}\text { MDR } \\
84-1\end{array}$ & $\begin{array}{c}\text { KBG } \\
89-1\end{array}$ & $\underset{45-1}{\text { MBR }}$ & $\begin{array}{l}\text { MDB } \\
106-1\end{array}$ & $\underset{73-1}{\text { MFM }}$ & $\begin{array}{c}\text { MCR } \\
19-1\end{array}$ & $\underset{17-1}{\operatorname{MBR}}$ & $\begin{array}{c}\text { PBL } \\
152-1\end{array}$ & $\begin{array}{l}\text { TFB } \\
37-1\end{array}$ & $\underset{94-1}{\text { MFM }}$ \\
\hline Lrl3-Adult & ; & ; & ; & 12 & 12 & 2 & 2 & $22+$ & $22+$ & $2+$ & 4 & 4 & 4 & 4 & 4 \\
\hline Lr13-Seedling & $3+c$ & $33+$ & $3 c$ & $3+$ & $3+$ & $3+$ & $3+$ & $3+$ & $3+$ & $3+$ & $3+$ & $3+$ & $3+$ & $3+$ & $3 c$ \\
\hline $\operatorname{Lr} 2 a$ & ;2 & 0 & 0 & $3+$ & $2+$ & 0 & $3+$ & 0 & 0 & 0 & 0 & 0 & ;2- & $3+$ & 0 \\
\hline $\operatorname{Lr} 2 a, 13$ & ; & 0 & 0 & $3+$ & $22+c$ & 0 & $3+$ & 0 & 0 & 0 & 0 & 0 & ;2- & $3+$ & 0 \\
\hline Lr11 & $12-$ & ;22- & ;2- & ;2- & $3+$ & $3+$ & $3+$ & $3+$ & ;22- & $; 2-$ & $3+$ & $3+$ & $2-$ & $2-$ & ;2- \\
\hline $\operatorname{Lr} 11,13$ & $; 1=$ & ;12-c & $; 1+$ & ;1-c & $3+$ & $3+$ & $3+$ & $3+$ & ;12- & ;2- & $3+$ & $3+$ & $2-$ & $2-$ & ;2- \\
\hline Lr17 & $; 1$ & $; 1$ & ;1- & $; 1$ & ;1- & $; 11+$ & ;1- & ;1- & $; 1$ & $; 1$ & $; 1$ & $; 1+$ & $; 1-$ & ;11+ & ;1- \\
\hline $\operatorname{Lr} 17,13$ & $; 1=$ & ;1-c & ; & ;1 & $; 1-$ & ;1 & $; 1$ & ;1- & ;1- & $; 1$ & $; 1$ & $; 1=$ & ;1- & ;1- & ;1- \\
\hline Lr30 & ;22- & ;2- & ;2- & ;22- & $3+$ & $3+$ & ;2- & $3+$ & ;2- & $33+$ & $3+$ & $3+$ & $23 c$ & $22-$ & $33+$ \\
\hline $\operatorname{Lr} 30,13$ & $; 1=$ & $; 1+c$ & $; 1-$ & ;11+ & $3+$ & $3+$ & ;2- & $3+$ & ;2- & $33+$ & $3+$ & $3+$ & $2+c$ & $22-$ & 3 \\
\hline Lr3ka & ;2- & $; 12=$ & $; 1=$ & $22-$ & $3+$ & $3+$ & ;12- & $3+$ & $; 2-c$ & $33+$ & $3+$ & $3+$ & $3+$ & $2-$ & 3 \\
\hline Lr3ka, 13 & $; 1=$ & $; 1+c$ & $; 1-$ & $; 22-c$ & $3+$ & $3+$ & $; 2-$ & $3+$ & $; 2-\mathrm{c}$ & $33+$ & $3+$ & $3+$ & $3+$ & $22+$ & $23-$ \\
\hline $\operatorname{Lr} 22 a$ & $3+$ & $3+$ & $33+$ & $3+$ & $3+$ & $3+$ & $3+$ & $3+$ & $3+$ & $3+$ & $3+$ & $3+$ & $3+$ & $3+$ & $33+$ \\
\hline Lr34 & $2+3$ & $2+3$ & $2+3$ & 23 & 23 & 23 & 23 & 23 & $2-3$ & 23 & 23 & 23 & 23 & $2+3$ & $23-$ \\
\hline Lr35 & $3+c$ & $33+$ & $33+$ & $33+c$ & $; 22+$ & $33+c$ & $33+c$ & $33+c$ & $33+c$ & $33+c$ & $33+$ & $33+$ & $33+c$ & $33+c$ & $2-3$ \\
\hline Lr37 & $X$ & $X$ & ;12- & X & X & ;23 & ;12 & X & X & X & ;23 & X & X & X & ;12- \\
\hline $\operatorname{Lr} 13,34$ & $2+3$ & 23 & 23 & 23 & 23 & 23 & 23 & 23 & 23 & 23 & $2+3$ & $22+c$ & 23 & $2+3$ & 23 \\
\hline Thatcher & 4 & $3+$ & $3+$ & $3+$ & $3+$ & $3+$ & $3+$ & $3+$ & 4 & $3+$ & $3+$ & $3+$ & $3+$ & $3+$ & $3+$ \\
\hline
\end{tabular}

a Infection types as described in Long and Kolmer (19). 
Kolmer (9) found that $\operatorname{Lr} 34$ enhanced resistance in seedling and adult plants only with other resistance genes that conditioned some degree of effective resistance when present singly. In rust nursery tests and farm fields, wheats with $\operatorname{Lr} 13,34$ can have variable levels of leaf rust severity, usually ranging from trace levels to $30 \%$, depending on the severity of the leaf rust epidemic. Interaction between $\operatorname{Lrl3}$ and Lr34, even to isolates that are completely virulent to Lr13, may help explain why wheats with this gene combination have had durable leaf rust resistance $(3,4,8,23)$. Interaction between $\operatorname{Lrl3}$ and $\mathrm{Lr} 34$ for enhanced resistance was not evident in the seedling test.

In the seedling test, lines with $\operatorname{Lrl3}$ paired with genes $L r 2 a, L r 11, L r 17, L r 3 k a$, and $L r 30$ best expressed resistance to isolates that had very low IT on adult plants of TcLr13, and had an intermediate IT on plants with the seedling resistance genes. Gene interaction was not as frequently observed with isolates that produced intermediate or high IT to adult plants of TcLr13, even though many of these isolates also produced intermediate IT on plants with some of the seedling resistance genes. Virulence of the isolates to adult plants with $L r 13$ affected the degree of interaction for enhanced resistance between resistance genes in seedling tests.

All isolates tested produced an IT X to plants with $L r 37$ in the seedling test. TcLr37 (6) is highly resistant in field tests (J. A. Kolmer, unpublished). Lr37 along with genes $L r 22 a$ and $L r 35$ offers additional sources of highly effective leaf rust resistance. These genes can be backcrossed into adapted germ plasm by screening progeny lines at the appropriate growth stage using $P$. recondita $\mathrm{f}$. $\mathrm{sp}$. tritici isolates virulent to the recurrent parent.

\section{ACKNOWLEDGMENTS}

I thank Peter Dyck for development of the Thatcher near-isogenic lines and P. Seto-Goh for excellent technical assistance.

\section{LITERATURE CITED}

1. Caldwell, R. M. 1968. Breeding for general and/or specific plant disease resistance. Pages 263-272 in: Third International Wheat Genetics Symposium. K. W. Finlay and K. W. Shepherd, eds. Butterworth \& Co., Sydney.

2. Dyck, P. L. 1987. The association of a gene for leaf rust resistance with the chromosome 7D suppressor of stem rust resistance in common wheat. Genome 29:467-469.

3. Dyck, P. L. 1993. The inheritance of leaf rust resistance in the wheat cultivar Pasqua. Can. J. Plant Sci. 73:903-906.

4. Dyck, P. L. 1993. Inheritance of leaf rust and stem rust resistance in 'Roblin' wheat. Genome 36:289-293.

5. Dyck, P. L., and Kerber, E. R. 1970. Inheritance in hexaploid wheat of adult-plant leaf rust resistance derived from Aegilops squarrosa. Can. J. Genet. Cytol. 12:175-180.

6. Dyck, P. L., and Lukow, O. M. 1988. The genetic analysis of two interspecific sources of leaf rust resistance and their effect on the quality of common wheat. Can. J. Plant Sci. 68:633-639.

7. Dyck, P. L., and Samborski, D. J. 1979. Adult-plant leaf rust resistance in PI 250413, an introduction of common wheat. Can. J. Plant Sci. 59:329-332.

8. Dyck, P. L., Samborski, D. J., and Anderson, R. G. 1966. Inheritance of adult-plant leaf rust resistance derived from the common wheat varieties Exchange and Frontana. Can. J. Genet. Cytol. 8:665-671.

9. German, S. E., and Kolmer, J. A. 1992. Effect of gene Lr34 in the enhancement of resistance to leaf rust of wheat. Theor. Appl. Genet. 84:97-105.

10. Kerber, E. R., and Dyck, P. L. 1990. Transfer to hexaploid wheat of linked genes for adultplant leaf rust and seedling stem rust resistance from an amphiploid of Aegilops speltoides $\times$ Triticum monococcum. Genome 33:530537.

11. Kolmer, J. A. 1989. Virulence and race dynamics of Puccinia recondita f. sp. tritici in Canada during 1956-1987. Phytopathology 79:349-356.

12. Kolmer, J. A. 1990. Physiologic specialization of Puccinia recondita f. sp. tritici in Canada in 1989. Can. J. Plant Pathol. 12:428430.

13. Kolmer, J. A. 1992. Enhanced leaf rust resistance in wheat conditioned by resistance gene pairs with Lr13. Euphytica 61:123-130.

14. Kolmer, J. A. 1992. Diversity of virulence phenotypes and effect of host sampling be- tween and within populations of Puccinia recondita f. sp. tritici in Canada. Plant Dis. 76:618-621.

15. Kolmer, J. A. 1994. Physiologic specialization of Puccinia recondita f. sp. tritici in Canada in 1993. Can. J. Plant Pathol. 16:326328.

16. Kolmer, J. A. 1996. Genetics of resistance to wheat leaf rust. Annu. Rev. Phytopathol. 34:435-455.

17. Kolmer, J. A. 1996. Physiologic specialization of Puccinia recondita $\mathrm{f}$. sp. tritici in Canada in 1994. Can. J. Plant Pathol. 18:300302.

18. Kolmer, J. A., Dyck, P. L., and Roelfs, A. P. 1991. An appraisal of stem and leaf rust resistance in North American hard red spring wheats and the probability of multiple mutations to virulence in populations of cereal rust fungi. Phytopathology 81:237-239.

19. Long, D. L., and Kolmer, J. A. 1989. A North American system of nomenclature for Puccinia recondita $\mathrm{f}$. sp. tritici. Phytopathology 79:525-529.

20. Long, D. L., Roelfs, A. P., and Roberts, J. J. 1992. Virulence of Puccinia recondita f. sp. tritici in the United States during 1988-1990. Plant Dis. 76:495-499.

21. Peterson, R. F., Campbell, A. B., and Hannah, A. E. 1948. A diagrammatic scale for estimating rust intensity on leaves and stems of cereals. Can. J. Res. 26:Section C:496-500.

22. Pretorious, Z. A., Kloppers F. J., and Drijepondt, S. C. 1994. Effect of inoculum density and temperature on three components of leaf rust resistance controlled by $\operatorname{Lr34}$ in wheat. Euphytica 74:91-96.

23. Roelfs, A. P. 1988. Resistance to leaf and stem rusts in wheat. Pages 10-22 in: Breeding Strategies for Resistance to the Rusts of Wheat. N. W. Simmonds and S. Rajaram, eds. CIMMYT, Mexico, D.F.

24. Roelfs, A. P., and Singh, R. P. 1992. Rust Diseases of Wheat: Concepts and methods of disease management. CIMMYT, Mexico, D.F.

25. Samborski, D. J., and Dyck, P. L. 1982. Enhancement of resistance to Puccinia recondita by interactions of resistance genes in wheat. Can. J. Plant Pathol. 4:152-156.

26. Stakman, E. C., Stewart, D. M., and Loegering, W. Q. 1962. Identification of physiologic races of Puccinia graminis var. tritici. U.S Dep. Agric. Agric. Res. Serv. E 6/7.

27. Steel, R. D., and Torrie, J. H. 1980. Principles and Procedures of Statistics. McGraw-Hill, New York. 